\title{
Geoecological assessment of mercury load in the impacted area of the thermal power plant of Seversk
}

\author{
E.E. Lyapina ${ }^{1,2}$, A.V. Talovskaya ${ }^{2}$, T.S. Shakhova ${ }^{2}$, I.A. Parygina ${ }^{2}$ \\ 1 - Institute of Monitoring of Climatic and Ecological Systems SB RAS. Academichesky ave., 10/3, \\ Tomsk, 634055, Russia \\ 2 - National Research Tomsk Polytechnic University, Tomsk
}

\begin{abstract}
The article deals with the experimental data, on which base the mercury level and modes of occurrence are detected in the insoluble fractions of aerosol in snow and in snowmelt water in the impacted areas of Seversk thermal power plant. The geochemical indices were calculated, the value of mercury load on the snow cover in the conventionally near field and far field impacted areas of fuel and energy complex enterprise was defined.
\end{abstract}

Key words: mercury, snow, aerosols, geochemistry, geoecology

\section{INTRODUCTION}

Enterprises of fuel and energy complex are the main source of anthropogenic pollution of the environment. From this perspective, the Thermal Power Plant (TPP) of Seversk is a significant source of dust aerosol emissions, which are spread at the distance of tens kilometers and settled down the underlying surface [11]. Seversk Thermal Power Plant is largest power plant in Tomsk region in production of electric and thermal power. The main fuel type is coal from Kuznetsky deposit, gas is an alternative type. Fuel oil is used for boilers ignition. There is always the three-month storage of coal in the power plant. The number of chimneys is five; the height of each is 125 meters. The main type of waste is an ash and slag mixture, which is disposed in the ash dumps. Coal in the plant is kept using open storage method, and it leads in turn to dusting and pollution of the atmosphere with coal dust.

Mercury if a first class hazard element in all naturel environments, it is characterized by diffused mode of occurrence in nature, increased migration capacity, superior bioavailability, as well as by wide range of negative impact on living organisms. Mentioned mercury features determine the interest of ecologists by investigation of this element in the environment. In addition, monitoring of mercury content in the components of the environment of cities, where there are no specialized "mercuries" industries, was provided by its high ecotixicity even in low concentrations $[4,12]$.

Atmospheric transfer carries out Mercury migration. The main method of atmospheric air purification from mercury is its dry and wet underlying surface deposition [1]. Snow cover is the most favorable deposit environment for obtaining of reliable data on income of pollutants from the atmosphere during the longest period in the Siberian region, when intensive use of different kinds of natural fuel (coal, gas, wood) for heat power engineering needs increases the load on urban ecosystems from the ecology point of view $[3,5]$.

Because of previously conducted areal snow and soil survey in the territory of Tomsk-Seversk industrial agglomeration, it was detected that technogenic mercury halos are observed in the location areas of enterprises of fuel and energy complex, instrument engineering, petrochemical plant and in the residential areas with prevailing stove heating and local boiler-houses $[5,8]$.

Snow cover as an accumulator of atmospheric fallouts in winter periods is widely used by many researchers for assessment of atmospheric air condition in the urban territories (Vasilenko, Saet et al., 1991; Boyarkina et al., 1993; Yazikov, Rikhvanov, 1994; 1996; 1999; Ilchenko, 2000; Letuvninkas, 2001; Shatilov, 2001, Aerosols of Siberia, 2006; Yazikov, 2006; Raputa, 2007; Talovskaya, 2008; Bortnikova et al., 2009 и others).

22nd International Symposium Atmospheric and Ocean Optics: Atmospheric Physics, edited by

Gennadii G. Matvienko, Oleg A. Romanovskii, Proc. of SPIE Vol. 10035, 1003570

(C) 2016 SPIE · CCC code: 0277-786X/16/\$18 - doi: 10.1117/12.2249286 
Urban soils are the source of information on long-term technogenic impact of industrial enterprises; in addition, they are the main physical and chemical barrier by migration of technogenic elements. Consequently, it is necessary to conduct the detailed ecological and geochemical assessment of their condition in the urban territory using the complex of mineralogical and geochemical methods. The health condition of population depends largely on the preservation and maintenance of natural ecological properties of urban soils.

The aim of the research is an assessment of mercury load according to the data of snow cover and soils investigation near Seversk Thermal Power Plant.

\section{METHODS AND OBJECTS OF RESEARCH}

At the end of winter period 2014, the authors conducted the snow sampling in the impacted area of Seversk Thermal Power Plant. The sizes of impacted areas of enterprises were defined according to [9], taking into account the prevailing wind direction (southern and southwestern), chimneys height, landscape and residential area character. In each of studied areas, 5 snow samples were collected. Snow sample collection and preparation were carried out based on guidelines $[1,9,13]$, supervision manual of air contamination [2,10] and long-term experience of ecogeochemical researches on the territory of Western Siberia [13]. The research object is an insoluble fraction of aerosol in snow (7 samples) and snowmelt water (7 samples). The testing range "Phonovyj" on the station of Institute of Atmospheric Optics, located not far from Kireevsk (70 km south of Tomsk) was chosen as a representative area.

For detection of interrelation between mercury content in the snow samples and soils in the impacted areas of Seversk Thermal Power Plant, in autumn 2014 the soil samples were collected. By soil sampling, we took into account wind direction, landscape and morphological peculiarities of the area, strength of emission sources and requirements for soil sampling (National State Standard 17.4.2.01-81, National State Standard 17.4.3.01-83, National State Standard 17.4.4.02-84, National State Standard 28168-89).

Snow and soil samples study was carried out in the educational laboratory of International Innovative Academic Center "Uranium Geology" based on the Geoecology and Geochemistry Department of National Research Tomsk Polytechnic University. Investigations of mercury content in the insoluble fraction of aerosol in snow were conducted on the Atomic Absorption Spectrometer RA-915+ with pyrolyzer PYRO-915 (pyrolysis reaction, mercury detection limit $5 \mathrm{mkg} / \mathrm{kg}$ ), snowmelt water samples - with attachment RP-91(cold vapor method, mercury detection limit - 0,005 $\mathrm{mkg} / \mathrm{dm}^{3}$ ). For detection of mercury modes of occurrence in in the insoluble fraction of aerosol in snow, the samples were analyzed with thermal desorption technique in different temperature conditions: $170-230^{\circ} \mathrm{C}, 370-430^{\circ} \mathrm{C}, 520-580^{\circ} \mathrm{C}$ and $680-740^{\circ} \mathrm{C}$ (pyrolyzer PYRO-915). For investigation of mercury distribution depending on the fraction of aerosol in snow, samples were sieved with the opening of $1 \mathrm{~mm}, 0,5 \mathrm{~mm}, 0,25 \mathrm{~mm}, 0,125 \mathrm{~mm}, 0,1 \mathrm{~mm}$ and $0,04 \mathrm{~mm}$.

\section{RESULTS AND DISCUSSION}

The research findings have shown, the dust load value in 2014 changed from 366 to $1030 \mathrm{mg} /\left(\mathrm{m}^{2} *\right.$ a day $)$ with distance from the chimneys of Thermal Power Plant northeastwards, from 179 to $238 \mathrm{mg} /(\mathrm{m} 2 * \mathrm{a}$ day) with distance from the chimneys southwestwards by the background value of $7 \mathrm{mg} /(\mathrm{m} 2 *$ a day) [13]. According to gradation [2], in winter 2014, the dust load value corresponded to high and very high pollution level northeastwards from the chimneys, and average southwestwards from the chimneys.

In comparison with Tomsk State District Power Plant (SDPP-2), the dust load value in the vicinity of Seversk Thermal Power Plant in 2014 differs in ten times. At the distance of 1,6 km from the chimneys the dust load value in the vicinity of Seversk Thermal Power Plant 30 times exceeds the value in Tomsk SDPP-2. These differences of the daily average dust fallout value can be explained by different heating capacity and kind of used fuel.

For comparison, the daily average value of mercury fallout from the atmosphere to the snow cover in the Tomsk SDPP-2 impacted area is $8,6 \mathrm{mg} /\left(\mathrm{km}^{2 *}\right.$ a day) northeastwards [10], in Seversk TPP is $226 \mathrm{mg} /(\mathrm{km} 2 *$ a day) that 26 times more than for Tomsk SDPP-2.

The average mercury content in the insoluble fraction of aerosol in snow near Seversk TPP in all investigated areas changes from 312 to $331 \mathrm{ng} / \mathrm{g}$, the differences of concentrations are within the limits of indication error. Mercury content in all samples changes from 5 to 7 backgrounds. The maximal average mercury concentrations are registered in the conventionally far-field impacted area of heat power engineering. In the conventionally near field and buffer (between Tomsk and Seversk) zones, the average values do not differ significantly. 
According to the research data of fly ash and slag for mercury content from this TPP, we can detect that mercury is mainly concentrated in the fly ash, and it indicates the mercury income by ash fraction of emissions. The mercury content in the fly ash is $0,2 \mathrm{mg} / \mathrm{kg}$, and in the slag is $0,0025 \mathrm{mg} / \mathrm{kg}$.

Calculated geoecological indices of mercury load near Seversk TPP represent the increased mercury content in the insoluble fraction of aerosol in snow from 5,47 to 5,81 times on the background concentrations. Comparing the data on the mercury content in the insoluble fraction of aerosol in snow with the indices of temporarily allowable concentration, the 7,25-7,71 excess of experimental data over the calculated ones should be mentioned. The maximum of all indices accounts for conventionally far-field impacted area of Seversk TPP. It is not unexpected that according to the literature data [7] on mercury transfer as a compound of aerosol particles, the most part of the pollutant is absorbed at the smallest fraction of aerosol particles, and therefore is transferred at far distances.

Values obtained by the calculation of aerosol accumulation indicates the mercury concentration at the dust aerosol particles compared to granite layer of the lithosphere to 10,6 times, that can be explained by some reasons. According to literature data [6], such behavior of mercury can be connected with the composition of initial matter forming dust aerosol, in case if atmospheric dust incoming from natural sources was initially enriched with mercury. But enrichment factor calculated to Sc, an element, which is widely spread in the earth crust, but has the lowest technophile and technogenic indices [7], has shown that dust aerosols from impacted areas of Seversk TPP are significantly enriched with mercury (from 4,3 to 6,3 times) because of anthropogenic impact, not because of lithophility of mercury. That is why the possible reason of high aerosol accumulation of mercury coming into the atmosphere in the gaseous form is an adsorption at the particles of atmospheric dust as a result of photochemical reactions; the most intensively the sorption process takes place in the fine particles of dust aerosols [6].

To confirm this observation, we have conducted an investigation for determination of mercury concentration in different fractions of aerosol particles. It was possible to identify that the maximal level of mercury in Seversk TPP emissions from 353 to $420 \mathrm{ng} / \mathrm{g}$ accounts for the largest fraction, with the size of larger than $0.25 \mathrm{~mm}$. The lowest concentrations occur in the magnetic fraction, from 34 to $80 \mathrm{ng} / \mathrm{g}$. In the conventionally near-field and buffer zones, the minimal mercury concentrations are in the compound of the particles with the size of $0.1 \mathrm{~mm}$, in the conventionally farfield zone are on particles with the size less than $0.04 \mathrm{~mm}$. However, by the equity proportion, mercury adsorbed to the smallest fraction of aerosol particles gives the larger contribution.

Researches for determining of modes of mercury occurrence in the compound of aerosol particles have shown that $90 \%$ of mercury contains in the elementary, free form $\left(\mathrm{Hg}_{0}\right)$. At the second place, on the aerosol particles in the emissions of Seversk TPP mercury presents in physically and chemically adsorbed form, to $60 \%$. The lowest mercury content in the insoluble fraction of aerosol in snow is in the isomorphic form, to $30 \%$. However, in absolute values, the maximal mercury content is marked in isomorphic fraction, i.e. as part of the crystalline grid of miners dust aerosol particles.

The snowmelt water investigations near Seversk TPP have shown, average mercury content in the snowmelt water varies from 0,01 to $0,23 \mathrm{mkg} / \mathrm{l}$, that 15 times exceeds the mercury concentration in the snowmelt water near SDPP2 of Tomsk $(0,015 \mathrm{mkg} / \mathrm{l})$. The average mercury content regarding to the background in the samples 43 times exceeds north-eastwards and 10 times exceeds south-westwards.

The reliable regularity of mercury concentration increase in snowmelt water with increase of proportion of loosely coupled (free) mercury mode in the compound of insoluble fraction of aerosol in snow was detected. The coefficient of mercury lability in snow cover is from 0,14 to 1,29 , it proves, mercury is a fluent element, which reacts to solution form in the process of snow melting.

The average mercury content in the soils of Seversk TPP impacted area is $95 \mathrm{ng} / \mathrm{g}$, which is slightly higher than the background concentration for soils of Tomsk region. However, in the conventionally near-field zone, the average mercury content is $146 \mathrm{ng} / \mathrm{g}$, but in the far-field zone it is $43 \mathrm{ng} / \mathrm{g}$. The greatest accumulation of mercury is detected in the conventionally near-field zone. It is observed a reverse tendency in comparison with the data on the insoluble fraction of aerosol in snow in the same impacted areas of Seversk TPP. Comparing the data on the mercury content of mercury in the insoluble fraction of aerosol in snow with the data of Hg investigations in soils in the same locations in the impacted areas of studied enterprises, we have detected the inverse relationship in the near-field zone $(\mathrm{r}=-1, \mathrm{P}=$ $0.95)$ and direct connection - in the far-field zone $(r=0,71, \mathrm{p}=0.95)$.

\section{CONCLUSIONS}

Then, on the base of conducted researches, the levels of mercury accumulation in the compound of dust aerosol particles in the impacted areas of Seversk TPP in winter period 2014. The greatest mercury concentrations in the 
insoluble fraction of aerosol in snow cover characterize the far-field area, where the excess of background values if to 5,9 times.

The calculations of ecogeochemical indices prove the fact that dust aerosols from impacted areas of industrial enterprises of Tomsk are significantly enriched with mercury due to the anthropogenic sources. Accumulation of mercury, which is in the air in gaseous form, in the dust aerosol particles occurs due to its sorption in the fine particles of dust aerosols.

Based on the research findings, the value of mercury load on snow cover in the conventionally near- and farfield impacted areas of Seversk TPP was detected. It was determined that the basic mass of mercury coming into the atmospheric air fall out in the far-field area, it is from 2 to 4,3 times more than in the near-field one. This regularity is connected mostly with the deficiency of high-rise buildings in the vicinity of power plant, which serve in the urban environment as a mechanical barrier on the pathway of plumes.

The conducted researches allow determining different modes of mercury occurrence in the insoluble fraction of aerosol in snow and their equity proportions. Such modes of mercury occurrence as free (elemental, loosely coupled), adsorbed (physically and chemically coupled) and isomorphic were detected. There are $90 \%$ of the elemental mercury (free mode of occurrence), up to $60 \%$ of physically and chemically adsorbed mercury, and up to $30 \%$ of isomorphic - the most tightly coupled - mode of mercury occurrence in the samples of insoluble fraction of aerosol in snow.

The research of snowmelt water has shown that the mercury concentrations in the soluble phase of snow cover in the impacted areas of industrial enterprises of Tomsk (from 10 to $230 \mathrm{ng} / \mathrm{dm}^{3}$ ) is in general comparable with similar data of other cities of Russia and of the world. The most intensive pass of mercury in solution during snow melting is observed in the near-field impacted area, where the proportion of water-soluble mode of mercury is from 40 to $85 \%$ of the whole mercury amount in the snow content.

Totally, the dust load in the impacted areas of Seversk TPP 30 times exceeds the dust load of Tomsk SDPP-2. However, the mercury load in the impacted areas of Tomsk SDPP-2 is 22 times lower than in the impacted areas of Seversk TPP.

\section{REFERENCES}

[1] Alyekhin Yu.V., Lapitskiy S.A., Mukhamadiyarova P.V., "The new results of research of separate components of a geochemical cycle of mercury", Theses of reports of an annual Russian seminar on experimental mineralogy, petrology and geochemistry, 91 (2009).

[2] Saiet B.A., Revitch E.P., Yanin E.P., [The Environment geochemistry], Moscow, Subsoil Недра, (1990). [3] Gerasimova N.N., "The analysis of influence of the enterprises of power system on environment components (on the example of the Kemerovo state district power station)", Theoretical and applied questions of modern geography. Materials of the All-Russian scientific conference, Tomsk, TSU, 135-136 (2009).

[4] Gladishev V.P., "Chemical dynamics and monitoring of mercury in environment", The materials of Russion symposium Of Control and rehabilitation of environment, Range, IAO SB RAS, 34-38 (2000).

[5] The state environmental standard 17.1.5.05.-85, [Conservation. Hydrosphere. General requirements to sampling of surface and seawater, ice and atmospheric precipitation], Moscow, Gidrometeoizdat, (1985).

[6] Dobrovolskyi V.V., [Fundamentals of biogeochemistry], Moscow, Academy, 400 (2003).

[7] Ivanov V.V., [Ecological geochemistry of elements], Moscow, Ecology 5, 576 (1997).

[8] Filimonenko E. A., Lyapina E. E., Talovskaya A. V., Parygina I. A., "Eco-geochemical peculiarities of mercury content in solid residue of snow in the industrial enterprises impacted areas of Tomsk", Proc. SPIE 9292, 20th International Symposium on Atmospheric and Ocean Optics: Atmospheric Physics, 929231 (November 25, 2014); doi: $10.1117 / 12.2075637$.

[9] Nazarov I.M., Fridman, Rene O.S. [Use network for research of sow for studying of pollution of snow cover], Russian Meteorology and Hydrology 7, $74-78$ (1978).

[10] Guide to control of pollution of the atmosphere РД 52.04.186-89, Moscow, Goskogidromet, 693 (1991).

[11] Functioning of power in the modern world, http://energetika.in.ua/ru/books/book-5/part-3/section-2.

[12] Yanin E.P., [Mercury in environment of the industrial city], Moscow, IMGRE, 169 (1992).

[13] Yazikov E.G., [Ecogeochemistry of the urbanized territories of the South of Western Siberia], Tomsk, 423 (2006). 